\title{
STUDY ON COMPARATIVE FLEXIBLE PAVEMENT THICKNESS ANALYSIS USING VARIOUS DESIGN METHOD
}

\author{
Gunalaan Vasudevan ${ }^{1}$, Hidayu Murni Bt Abu hussain ${ }^{2}$ \\ ${ }^{I}$ Faculty of Engineering and Built Environment, Lecturer, Tunku Abdul Rahman University College, Malaysia \\ ${ }^{2}$ Department Highway, Engineer HSS Sdn. Bhd, Malaysia
}

\begin{abstract}
Recently, there is a lot of variability in guide to design a pavement. Although all kinds method available, but still pavement suffers damage caused by unstable thickness. It is critical to determine the most appropriate pavement thickness for a given traffic level and subgrade condition. To overcome the problems, there is a need to study the comparative pavement thickness analysis using various pavement design methods so that it will be cost effective and long lasting. The input parameters in flexible pavement design are identified and have been used in obtaining different pavement layer thickness by conducting various pavement design method, that is Arahan Teknik (Jalan) 5/85 Jabatan Kerja Raya (JKR), AASHTO Method and Asphalt Institute Thickness Design Program (SW-1). Finding from this study indicate that thickness from Arahan Teknik (Jalan) 5/85 Jabatan Kerja Raya (JKR) gave better results than the others because it produced more thinner flexible pavement layer compared to the two other design method. In terms of cost, it will be more cost effective since the cost of material can be reduced.
\end{abstract}

Keywords: Flexible Pavement, AASHTO and Asphalt Institute Thickness Design

\section{INTRODUCTION}

The purpose of a pavement is to carry traffic safely, conveniently and economically over its extended life. The pavement must provide smooth riding quality with adequate skid resistance and have adequate thickness to ensure that traffic loads are distributed over an area so that the stresses and strains at all levels in the pavement and subgrade are within the capabilities of the materials at each level. The performance of the pavement therefore related to its ability to serve traffic over a period of time. From the day it is opened to traffic, a pavement will suffer progressive structural deterioration. It is possible that the pavement may not fulfill its intended function of carrying a projected amount of traffic during its design life, because the degree of deterioration is such that reconstruction or major structural repair is necessitated before the end of the design life. There are two main types of failure, functional and structural, associated with pavement deterioration. Functional failure is that wherein the pavement is unable to carry traffic without causing discomfort to the road users. This failure depends primarily upon the degree of surface roughness. Structural failure, on the other hand, indicates a breakdown of one or more component making it incapable of sustaining the loads imposed upon its surface. In flexible pavements, this failure may result from bituminous surface fatigue, consolidation, settlement, and shear developing in the subgrade or inadequate performance of the subs, road base, and surface, as a result of inadequate pavement thickness

\section{LITERATURE REVIEW}

\subsection{Flexible Pavement}

Flexible pavements are those which are surfaced with bituminous (or asphalt) materials. These types of pavements are called "flexible" since the total pavement structure "bends" or "deflects" due to traffic loads. A flexible pavement structure is generally composed of several layers of materials which can accommodate this "flexing". Flexible pavements comprise more than 90 percent of our paved roads.

There are many different types of flexible pavements. It covers three of the more common types of Hot Mix Asphalt (HMA) mix types commonly used. Other flexible pavements such as bituminous surface treatments (BSTs) are considered by most agencies to be a form of maintenance and are thus covered under maintenance and rehabilitation. HMA mix types differ from each other mainly in maximum aggregate size, aggregate gradation and asphalt binder content or type. Guides are available on dense-graded HMA in most flexible pavement sections because it is the most common HMA pavement material. (HAPI, 2002).components makes it incapable of sustaining the loads imposed upon its surface. In flexible pavements, this failure may result from bituminous surface fatigue, consolidation, settlement, and shear developing in the subgrade or inadequate performance of the subs, road base, and surface, as a result of inadequate pavement thickness. 


\subsection{Pavement Design}

Effective pavement design is one of the important aspects of project design. The pavement is the portion of the highway, which is most obvious to the motorist. The condition and adequacy of the highway are often judged by the smoothness or roughness of the pavement. Deficient pavement conditions can result in increased user costs and travel delays, braking and fuel consumption, vehicle maintenance repairs and the probability of increased crashes. The pavement life is substantially affected by the number of heavy load repetitions applied, such as single, tandem, tridem and quad axle trucks, buses, tractor trailers and equipment. A properly designed pavement structure will take into account the applied loading. (Mass Highway, 2006). The primary function of the pavement structure is to reduce and distribute the surface stresses (contact tire pressure) to an acceptable level at the subgrade (to a level that prevents permanent deformation).

A flexible pavement reduces the stresses by distributing the traffic wheel loads over greater and greater areas, through the individual layers, until the stress at the subgrade is at an acceptably low level. The traffic loads are transmitted to the subgrade by aggregate-to-aggregate particle contact. Confining pressures (lateral forces due to material weight) in the subbase and base layers increase the bearing strength of these materials. A cone of distributed loads reduces and spreads the stresses to the subgrade. (Fred L. et al, 2004)

\subsection{Factors to be considered}

The information obtained from the explorations and the test should be adequate to enable full consideration of all factors affecting the suitability of the subgrade and subsoil. The primary factors are as follows:

- The general characteristics of the subgrade soils such as soil classification, limits, etc.

- Depth to bed rock.

- Depth to water table (including perched water table).

- The compaction that can be attained in the subgrade and the adequacy of the existing density in the layers below the zone of compaction requirements.

- The CBR that the compacted subgrade and uncompact subgrade will have under local environmental conditions. In-place densities are satisfactory.

- The presence of weak of soft layers in the sub-soil.

- Susceptibility to detrimental frost action

\subsection{Selection of Material and Sub Base Course}

\subsubsection{General}

It is common practice in pavement design to use locally available or other readily available materials between the subgrade and base course for the economy. These layers are designated as select materials or sub bases. Those with design
CBR values equal to or less than 20 are designated select materials, and those with CBR values above 20 are designated sub bases. Minimum thicknesses of pavement and base have been established to eliminate the need for sub bases with design CBR values above 50. Where the design CBR value of the subgrade without processing is in the range of 20 to 50, select materials and sub bases may not be needed. However, the subgrade cannot be assigned design CBR values of 20 or higher unless it meets the gradation and plasticity requirements for sub bases.

\subsubsection{Materials}

The investigations described above will be used to determine the location and characteristics of suitable soils for select material and sub base construction. Select materials will normally be locally available coarse grained soils (prefix $\mathrm{G}$ or $\mathrm{S}$ ), although fine-grained soils in the ML and CL groups may be used in certain cases. Lime rock, coral, shell, ashes, cinders, cliche, disintegrated granite, and other such materials should be considered when they are economical.

\subsubsection{Sub Base Materials}

Sub base materials may consist of naturally occurring coarsegrained soils or blended and processed soils. Materials such as lime rock, coral, shell, ashes, cinders, cliche, and disintegrated granite may be used as sub bases when they meet the requirements. The existing subgrade may meet the requirements for a sub base course or it may be possible to treat the existing subgrade to produce a sub base. However, admixing native or processed materials will be done only when the unmixed subgrade meets the liquid limit and plasticity index requirements for sub bases. It has been found that "cutting" plasticity in this way is not satisfactory. Material stabilized with commercial additives may be economical as a sub base. Portland cement, lime, flash, or bitumen and combinations thereof are commonly employed for this purpose. Also, it may be possible to decrease the plasticity of some materials by use of lime or Portland cement in sufficient amounts to make them suitable as sub bases

\section{METHODOLOGY}

The methodology adopted for this study has been limited to three design method, that are, Jabatan Kerja Raya (JKR) "Arahan Teknik Jalan 5/85" design procedure, American Association of State Highway and Transportation Officials (AASHTO) 1993 design procedure and Asphalt Institute Design Procedure (SW-1 Program) 


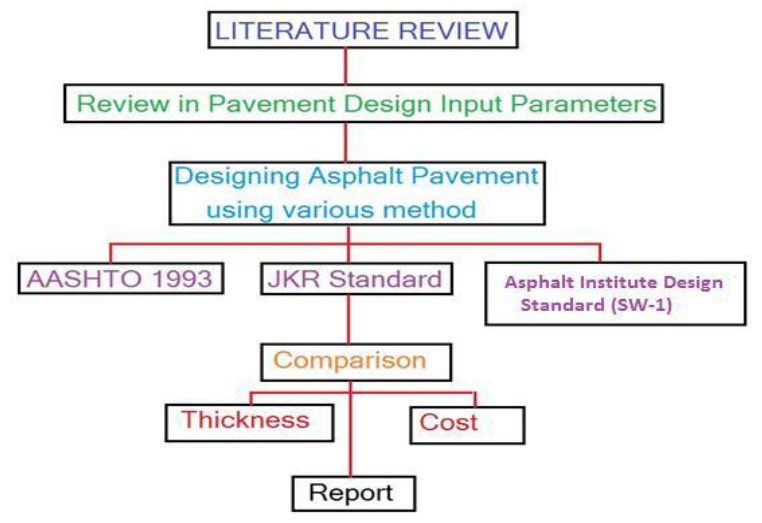

Fig 1 Flow Chart Methodology

\subsection{Input Parameters}

For each design standard, input parameters must be determined before designing flexible pavement layer thickness accordingly. For this case study, input parameters that will be used to design new flexible pavement layer thickness are as follows:

- Initial Daily Traffic Volume (ADT)

- Percentage of commercial vehicle, Pc

- Annual growth rate,

- Equivalent factor, e

- $\quad$ Subgrade CBR value (\%)

- Equivalent Standard Axles (ESAL)

- Reliability, R

- Serviceability Index

- Directional lane distribution

- Lane distribution

- Standard deviation

- Effective subgrade modulus

- Structural numbers, SN

\subsection{Asphalt Institute (AI), Thickness Design Programme SW-1}

\subsubsection{Basic Operation}

SW-1 was designed for pavement design professionals who may have the need to design pavements for a wide variety of uses including airports, roadways, and parking lots. Rather than turn to individual specialty programs for each type of pavement, the SW-1 integrates its pavement thickness design tools in a single program for exceptional versatility. The key to this versatility lies in the Project Definition screen, SW-1's opening screen. On the Project Definition screen you can define the project to be designed by selecting the Pavement Use (i.e. General aviation airport or highways, roadways, and streets) and the Project Type (i.e. New pavement or overlay). Once you define the project, SW-1 creates the proper tabs to step you through the specific design problem-at-hand. This chapter covers basic operations that are common to all pavement designs completed in SW-1. This includes file operations, managing data files, screen layout, managing project records, defining units, project definition, view results, and printing from SW-1.

\subsubsection{Subgrade}

On the subgrade screen, the user is asked to supply subgrade stiffness values as inputs to the pavement section design calculation. SW-1 uses the resilient modulus to characterize subgrade stiffness, but can correlate from CBR or R-values is the user has this type of information. The user is asked to select the type of strength measure, input the stiffness values, and select a design subgrade value in order to calculate the Design Subgrade Resilient Modulus.

\subsubsection{Types of Strength Measure}

The basis for subgrade strength measurement in this program is the subgrade resilient modulus, which can be determined from a laboratory test in accordance with AASHTO Method T 307. In order to facilitate the use of other widely used tests, correlations have been established by the California Bearing Ratio (CBR) and the Resistance (R) value. Procedures for performing CBR and R-value tests are detailed in MS-I0 and ASTM/ AASHTO test methods: In SW-1 the default relationship used to correlate resilient modulus from a CBR test value is as follows, but may be changed by the user:

$$
\operatorname{Mr}(\mathbf{p s i})=1500 \mathrm{CBR}
$$

Similarly, the default relationship used by SW-1 to correlate resilient modulus from an $\mathrm{R}$-value test is as follows:

$$
\operatorname{Mr}(\text { psi })=1155+555(\text { R-value })
$$

CBR and R-value correlations are considered applicable to fine-grained soils classified as CL, CH, ML, SC, SM, and SP (Unified Soil Classification) or for materials that are estimated to have a resilient modulus of $30,000 \mathrm{psi}$ or less. These correlations are not applicable to granular materials, such as base aggregate, which may require direct laboratory testing to obtain resilient modulus values.

\subsubsection{Selection of Design Value}

The Design Subgrade Resilient Modulus is the value of the subgrade resilient modulus (MR) used for designing the pavement structure. It is a percentile value of the subgrade resilient modulus test data distribution. One or more individual data points may be used to characterize subgrade stiffness. If a single value is used, SW-1 selects it as the design value. This procedure allows the user to look at the statistical significance of the data set before selecting the design value. It requires more conservatism as the traffic volume increases and allows for less conservatism on low volume designs. 


\section{RESULTS}

This section consists of three major design procedure that is Arahan Teknik (Jalan) 5/85 Jabatan Kerja Raya (JKR) Manual, AASHTO 1993 Design Method and Asphalt Institute Thickness Design SW-1Program. The input parameters are as follows and have been taken from Unit Pavemen Dan Kejuruteraan Trafik Cawangan Kejuruteraan Jalan \& Geoteknik Ibu Pejabat Jabatan Kerja Raya for Project, Membina Jalan Dari Kg. Timah SKC Ke Taman Bunga Raya Bukit Beruntung, Selangor.

\subsection{Asphalt Institute Thickness Design Program} (SW-1)

\section{STEP 1: Project Definition}

Choose the Gravel Base Problem as to construct New Pavement Design:

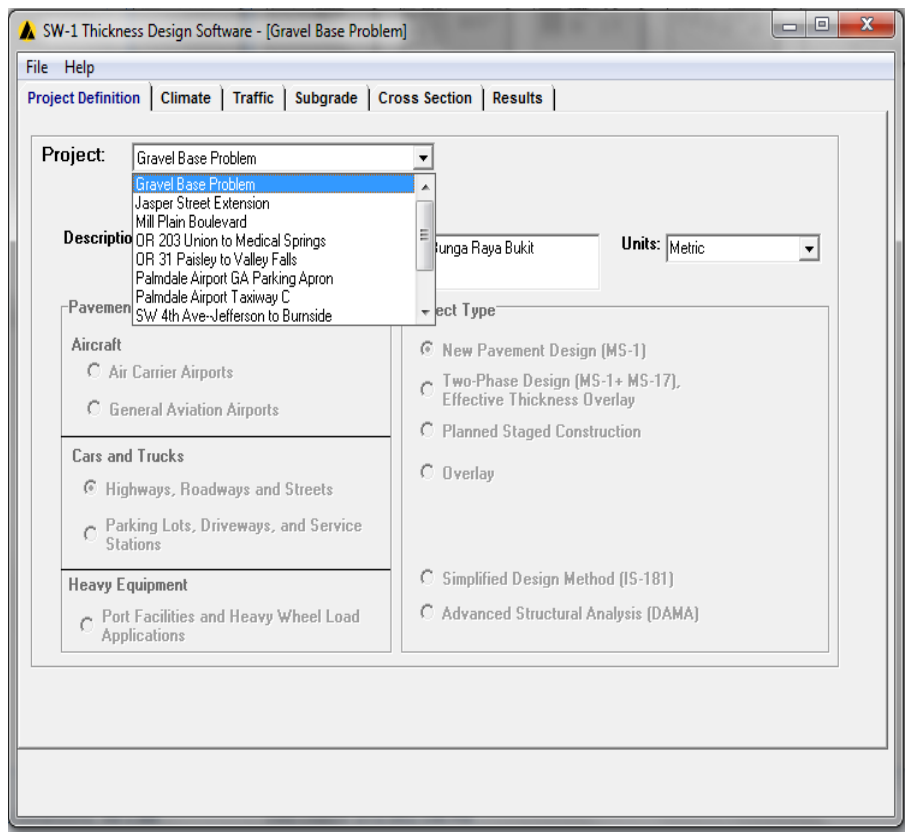

Fig 2: Choosing gravel base problem to construct new road

Insert "Cadangan Membina Jalan Dari Kampung Timah SKC ke Taman Bunga Raya Bukit Beruntung, Selangor" as the description of the new project:

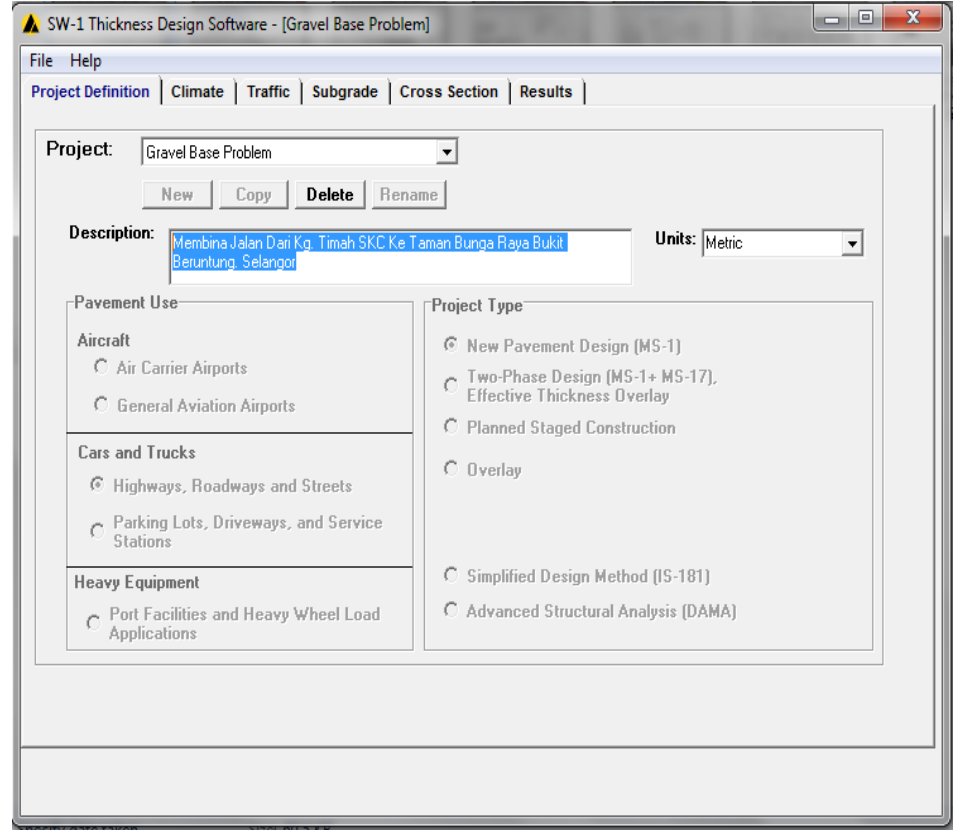

Fig 3: Inserting the name of the project

Choose Metric as the Standard Unit for this design:

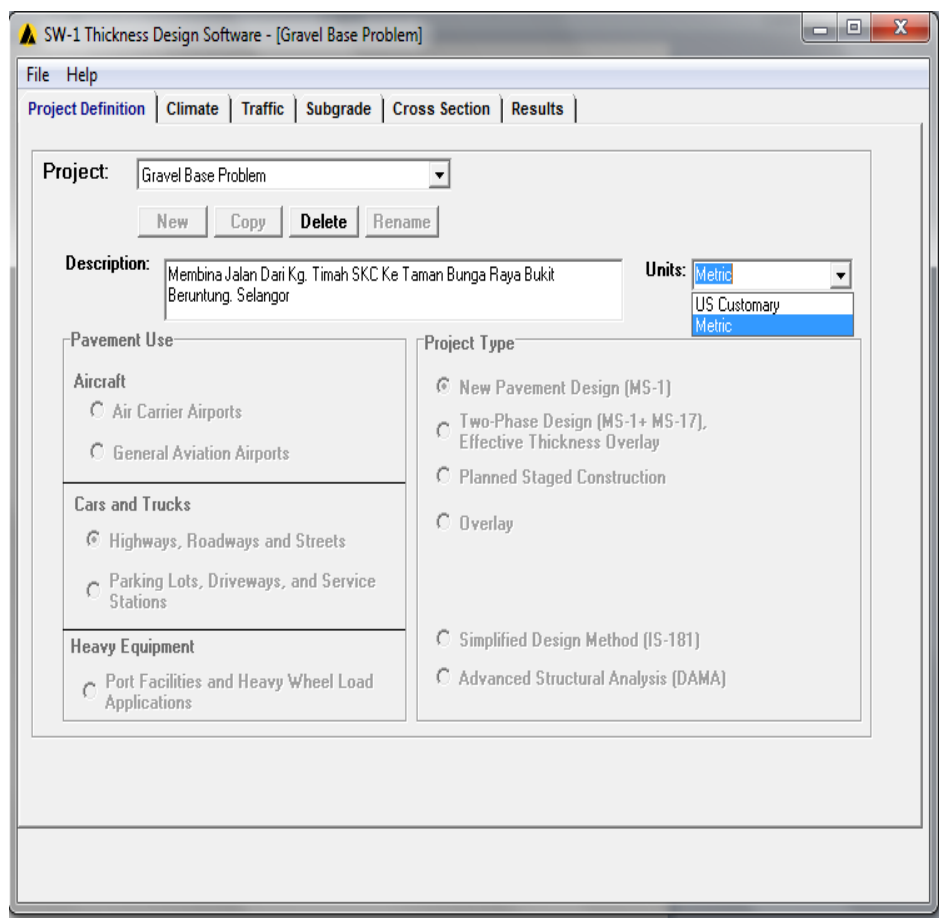

Fig 4: Choosing Metric as the units

\section{STEP 2: Climate}

Insert Environmental Conditions for this pavement design. For that we are in Malaysia, no frost effects. 


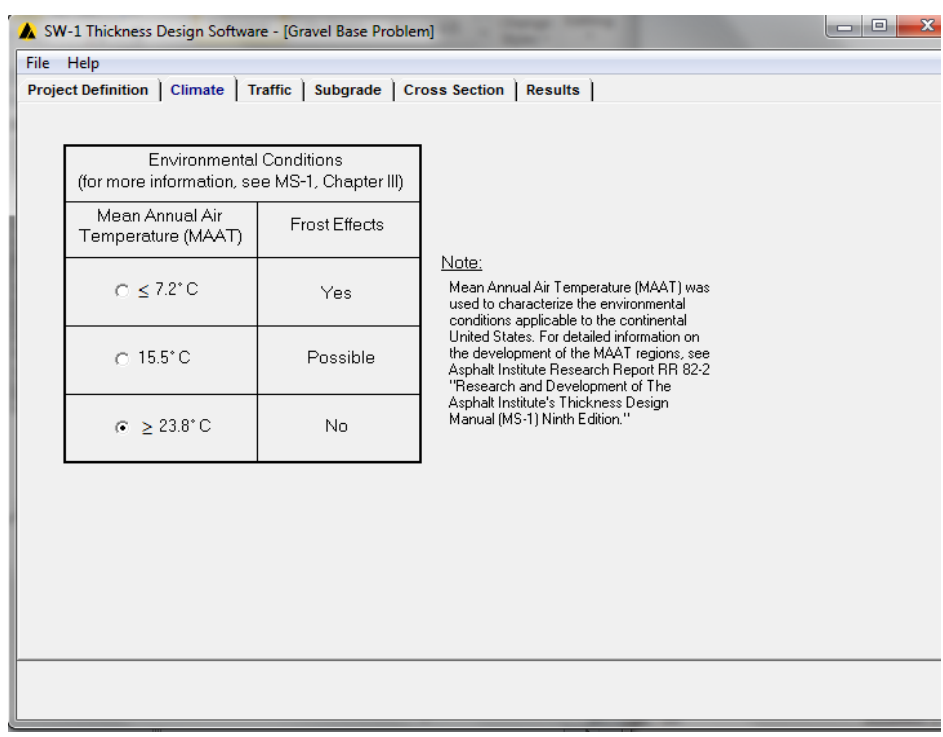

Fig 5: Inserting environmental conditions

\section{STEP 3: Traffic Information}

In this tab, all the input parameters have been inserted to calculate the Equivalent Single Axle Load (ESAL). The Design, Period ESAL should show 139,652 ESALs over the expected 10-year life

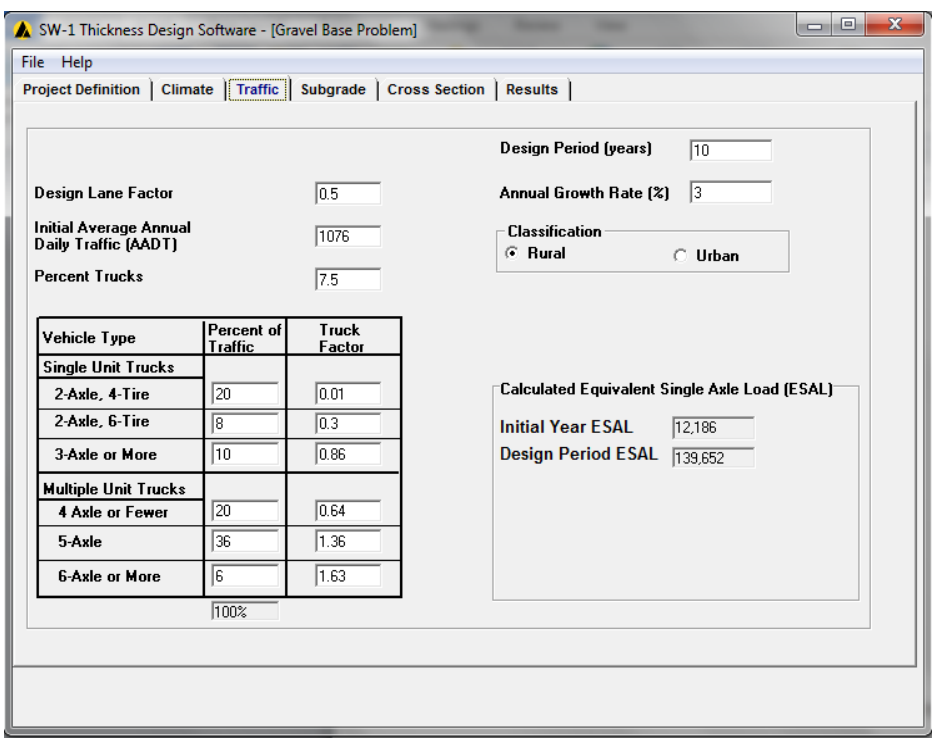

Fig 6: Inserting Traffic Information

\section{STEP 4: Subgrade}

Select California Bearing Ration (CBR) as the type of strength measure. The CBR value for subgrade is $5 \%$. Recommended design strength percentile is $75 \%$. From the input data, Design $\mathrm{Mr}$ is $51.5 \mathrm{MPa}$.

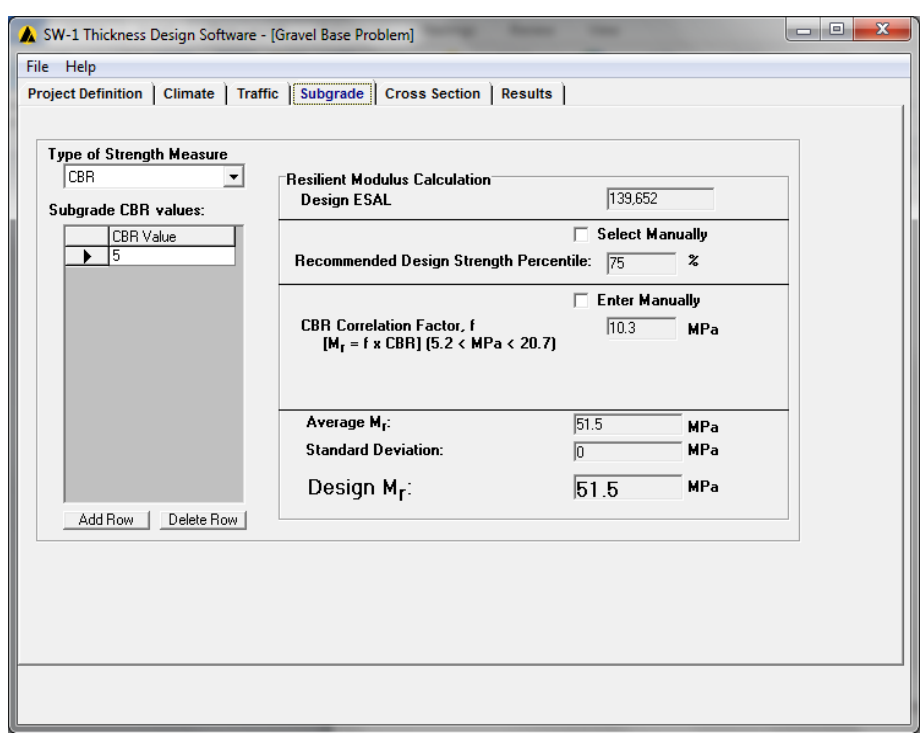

Fig 7: Inserting type of strength measure

\section{STEP 5: Cross Section for Flexible Pavement}

From the SW-1 Guideline, Type 3 radial button corresponding to an aggregate base thickness of 12 inches has been selected.

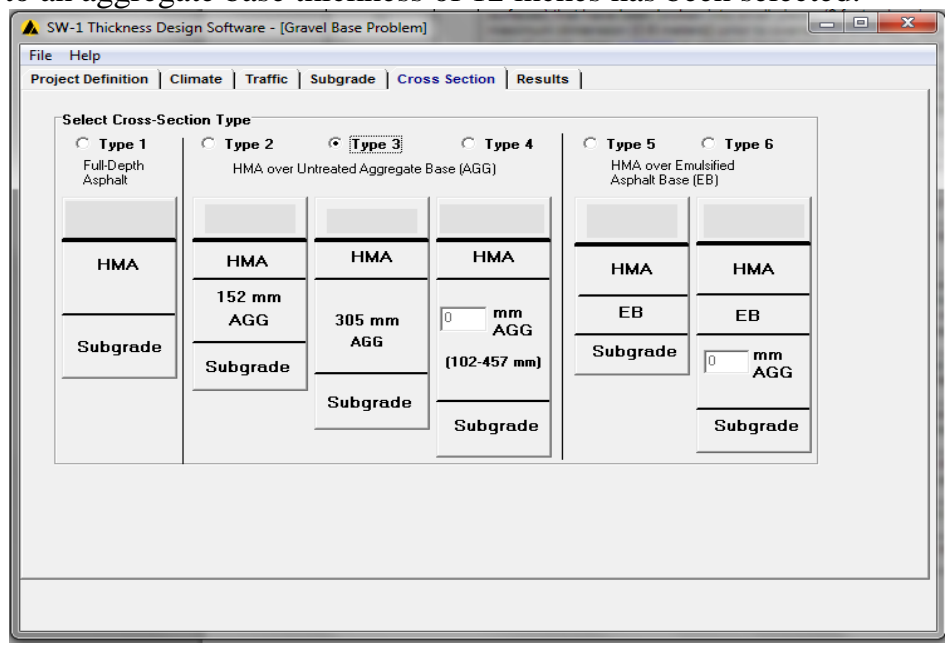

Fig 8: Selection of cross-section type

\subsection{Summary of Asphalt Institute Method}

Table 1: Result and Design Summary for Asphalt Institute Method

\begin{tabular}{|l|l|}
\hline Project Information & \\
\hline Project Name: & Gravel Base Problem \\
\hline Description: & $\begin{array}{l}\text { Membina Jalan Dari } \\
\text { Kg. Timah SKC Ke } \\
\text { Taman Bunga Raya } \\
\text { Bukit Beruntung. } \\
\text { Selangor }\end{array}$ \\
\hline
\end{tabular}




\begin{tabular}{|c|c|}
\hline Pavement Use: & General Roadway \\
\hline Problem Type: & $\begin{array}{ll}\text { New } & \text { Pavement } \\
\text { Design } & \end{array}$ \\
\hline Design Input Summary & \\
\hline Climate: & $24^{\circ} \mathrm{C}$ \\
\hline Design Traffic (ESAL): & 139,652 \\
\hline Subgrade $\mathrm{Mr}(\mathrm{MPa})$ : & 51.5 \\
\hline Design Traffic Details & \\
\hline Design Life (years): & 10 \\
\hline Design Lane Factor: & 0.5 \\
\hline $\begin{array}{l}\text { Initial Average Annual Daily } \\
\text { Traffic (AADT): }\end{array}$ & 1076 \\
\hline $\begin{array}{l}\text { Truck Volume, as a } \\
\text { percentage of AADT: }\end{array}$ & 7.5 \\
\hline $\begin{array}{l}\text { Annual Compound Growth } \\
\text { Rate }(\%) \text { : }\end{array}$ & 3 \\
\hline Type of usage: & Rural \\
\hline Calculated Equivalent Single & Axle Loads (ESAL) \\
\hline Initial Year Traffic (ESAL): & 12,186 \\
\hline Design Life (ESAL): & 139,652 \\
\hline Subgrade Information & \\
\hline Type of Measurement: & $\begin{array}{l}\text { California Bearing } \\
\text { Ratio(CBR) }\end{array}$ \\
\hline Correlation Equation: & $\begin{array}{l}\mathrm{Mr}(\mathrm{MPa})=[10.3 \mathrm{x} \\
\text { CBR }]\end{array}$ \\
\hline $\begin{array}{ll}\text { Recommended } & \text { Design } \\
\text { Strength Percentile } & \end{array}$ & 75.0 \\
\hline Design Strength Percentile: & N/A \\
\hline IndividulCRR Values & CBR $\mathrm{Mr}$ \\
\hline & 5 \\
\hline Average: & 52 \\
\hline Std Dev: & 0 \\
\hline Design $\mathrm{Mr}$ & 52 \\
\hline Design Results & \\
\hline HMA Thickness (mm) & 101.6 \\
\hline $\begin{array}{l}\text { Aggregate Base Thickness } \\
(\mathrm{mm})\end{array}$ & 304.8 \\
\hline
\end{tabular}

\section{SW-1 Thickness Design Software version 1.0}

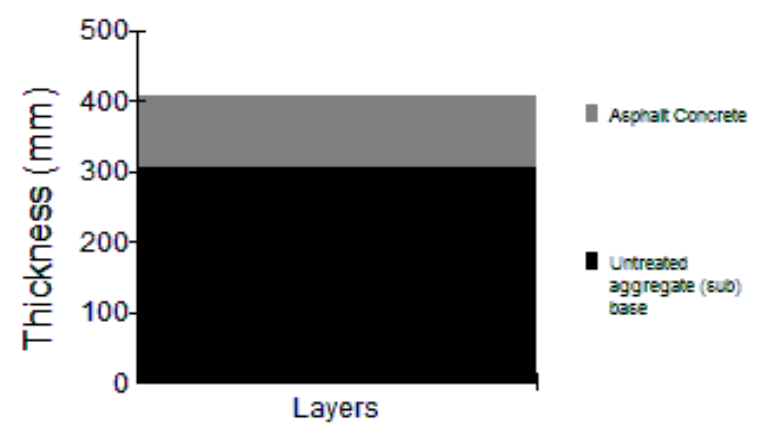

Fig 9: Pavement Layer Thickness obtained from Asphalt Institute Design Programme SW-1

From the result obtained, it shows that the Hot Mix Asphalt is $101.6 \mathrm{~mm}$ while the Aggregate Base Thickness is $304.8 \mathrm{~mm}$. Hence the total pavement layer thickness is $406.4 \mathrm{~mm}$.

\subsection{Comparison Pavement Layer Thickness}

Table 2: Pavement layer thickness of each standard accordingly

\begin{tabular}{|c|c|c|c|}
\hline & $\begin{array}{l}\text { JKR } \\
\text { Standard }\end{array}$ & $\begin{array}{l}\text { AASHTO } \\
\text { Standard }\end{array}$ & $\begin{array}{l}\text { Asphalt } \\
\text { Institute } \\
\text { (SW-1 } \\
\text { Programme) }\end{array}$ \\
\hline $\begin{array}{l}\text { Asphalt Layer } \\
(\mathrm{mm})\end{array}$ & 90.0 & 101.6 & 101.6 \\
\hline $\begin{array}{l}\text { Base Layer } \\
(\mathrm{mm})\end{array}$ & 150.0 & 152.0 & \multirow{2}{*}{304.8} \\
\hline $\begin{array}{l}\text { Sub Base } \\
\text { Layer }(\mathrm{mm})\end{array}$ & 100.0 & 279.4 & \\
\hline $\begin{array}{l}\text { Total Layer } \\
\text { Thickness } \\
(\mathrm{mm})\end{array}$ & 340.0 & 533.0 & 406.0 \\
\hline
\end{tabular}

Table 2 shows the comparison in pavement layer thickness of each standard accordingly. Between three methods that have been used, it is clear that JKR Standard gave the thinner pavement layer compared to the others. This condition happened because JKR Standard was enacted based on Malaysia's road suitability. From the table, JKR Design procedure produced $90 \mathrm{~mm}$ of HMA layer thickness followed by $150 \mathrm{~mm}$ in base course and $100 \mathrm{~mm}$ for the sub base course. This is different with AASHTO layer thickness value that gave $101.6 \mathrm{~mm}$ for asphalt layer, $152 \mathrm{~mm}$ for base course layer and followed by $279.4 \mathrm{~mm}$ for the sub base layer. 
Pavement layer thickness that has been produced by the Asphalt Institute SW-1 Program is $101.6 \mathrm{~mm}$ for asphalt layer and $304.8 \mathrm{~mm}$ for combination road base and sub base layer. AASHTO gave thicker Aggregate Base layer because too much variables needed in the standard and in order to reduce rehabilitation costs so that the road will be long lasting.

Table 3: Comparison in layer thickness between JKR Standard and AASHTO Standard

\begin{tabular}{|l|l|l|l|}
\hline & $\begin{array}{l}\text { JKR } \\
\text { Standard }\end{array}$ & $\begin{array}{l}\text { AASHTO } \\
\text { Standard }\end{array}$ & Differences (\%) \\
\hline $\begin{array}{l}\text { Asphalt Layer } \\
(\mathrm{mm})\end{array}$ & 90.0 & 101.6 & 11.42 \\
\hline $\begin{array}{l}\text { Base Layer } \\
(\mathrm{mm})\end{array}$ & 150.0 & 152.0 & 1.32 \\
\hline $\begin{array}{l}\text { Sub Base Layer } \\
(\mathrm{mm})\end{array}$ & 100.0 & 279.4 & 64.20 \\
\hline $\begin{array}{l}\text { Total Layer } \\
\text { Thickness (mm) }\end{array}$ & 340.0 & 533.0 & 36.20 \\
\hline
\end{tabular}

Table 3 shows the differences in layer thickness and percentage between JKR Design Standard and AASHTO Design Standard. There are 11.42 percent differences in the asphalt layer between both methods. But the base layer had given not so much difference that is only 1.32 percent. For sub base layer, it recorded about 64.2 percent differences and the total for flexible pavement layer thickness; it is clearly shown that JKR Design Standard is much lower than the AASHTO Design Standard with 36.20 percent difference.

Table 4: Comparison in layer thickness between JKR Standard and Asphalt Institute Design Standard (SW-1 Programme)

\begin{tabular}{|l|l|l|l|}
\hline & $\begin{array}{l}\text { JKR } \\
\text { Standard }\end{array}$ & $\begin{array}{l}\text { Asphalt } \\
\text { Institute } \\
\text { Standard }\end{array}$ & $\begin{array}{l}\text { Differences } \\
(\%)\end{array}$ \\
\hline $\begin{array}{l}\text { Asphalt Layer } \\
(\mathbf{m m})\end{array}$ & 90.0 & 101.6 & 11.42 \\
\hline $\begin{array}{l}\text { Base Layer } \\
(\mathbf{m m})\end{array}$ & 150.0 & 304.8 & 50.79 \\
\hline $\begin{array}{l}\text { Sub Base Layer } \\
\text { (mm) }\end{array}$ & 100.0 & - & - \\
\hline $\begin{array}{l}\text { Total Layer } \\
\text { Thickness (mm) }\end{array}$ & 340.0 & 406.4 & 16.34 \\
\hline
\end{tabular}

Table 4 shows the comparison in layer thickness between JKR Standard and Asphalt Institute Design Standard (SW-1 Programme). From the table, asphalt layer thickness between both standard slightly different with only 11.42 percent of differences. At the meanwhile, base layer thickness shows the very big difference with 50.79 percent of differences. Overall, it is shown that total layer thickness from Asphalt Institute Design Standard (SW-1 Program) gave the thicker pavement layer with 16.34 percent difference compared to JKR Design Standard.

\subsection{Differences in Asphalt Layer Thickness}

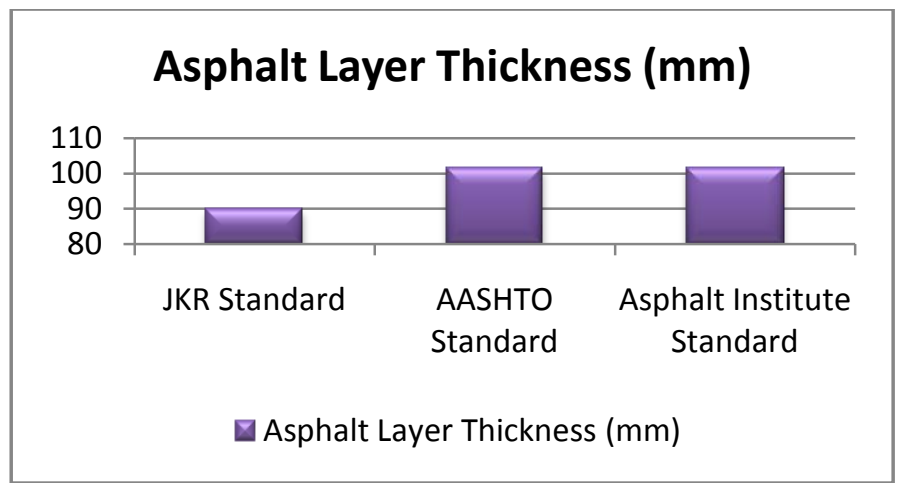

Fig 10: Differences in Asphalt Layer Thickness

From Figure 10, it can be seen that AASHTO Design Standard and Asphalt Institute Design Standard gave the same thickness of asphalt layer compared to JKR Design Standard. There is 11.42 percent of differences in layer thickness between JKR Design Standard and AASHTO Design Standard. Same goes with Asphalt Institute Design Standard which was recorded same asphalt layer thickness with the AASHTO Design Standard.

\subsection{Differences in Base and Sub base Layer}

\section{Thickness}

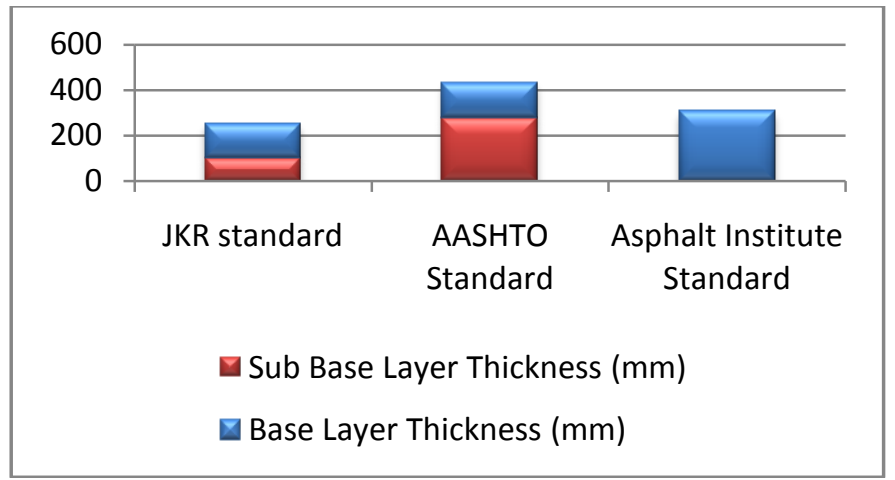

Fig 11: Differences in Base and Sub base Layer Thickness

From the bar chart in Figure 11, it is clearly shown that AASHTO Standard gave the highest value in base $(152 \mathrm{~mm})$ and sub base $(279.4 \mathrm{~mm})$ layer thickness compared to the other standard. Asphalt Institute recorded the second highest value in the base and sub base layer thickness which gave total $304 \mathrm{~mm}$ for base thickness and followed by the JKR Design 
Standard that gave $150 \mathrm{~mm}$ base thickness and $100 \mathrm{~mm}$ sub base layer thickness. The differences between AASHTO Design Standard and JKR Design Standard for base and sub base layer thickness is about 42.05 percent and the differences base and sub base layer thickness between JKR Standard and Asphalt Institute Standard is not that far, that is only 18.0 percent. For base and sub base layer thickness, AASHTO gave the highest value. This is because AASHTO Design Standard are based on the empirical design method.

\subsection{Cost Comparison}

Table 5: Cost Comparison

\begin{tabular}{|l|l|l|l|}
\hline \multicolumn{1}{|l|}{ Cost } & JKR & AASHTO & A. Institute \\
& (RM) & (RM) & (RM) \\
\hline HMA Layer & 288,000 & 325,120 & 325,120 \\
\hline RM 400/m3 & & & \\
\hline Base Layer & 76,260 & 77,277 & 154,960 \\
\hline RM 63.55/m3 & & & \\
\hline Sub Base Layer & 32,640 & 91,196 & \\
\hline RM 40.80/m3 & & \\
\hline TOTAL & 396,900 & 493,593 & 480,000 \\
\hline
\end{tabular}

From Table 4.5, it is shown that the AASHTO Design Standard gave the highest cost compared to JKR and Asphalt Institute Design Standard that is RM 493,593. The second highest cost estimate is Asphalt Institute, which gave RM 480,000 then followed by JKR Design Standard which gave only RM 396,900. AASHTO Design Standard and Asphalt Institute Design Standard recorded not so much difference in terms of cost, that is only 2.75 percent. But between JKR Design Standard and AASHTO Design Standard, the differences are almost RM100, 000 that is a 19.6 percent difference. The possible causes are because the sub base layer thickness produced by AASHTO Design Standard was too thick to protect subgrade layer which only gave 3 percent of CBR value. Hence, the cost of the thick sub base affects the total cost to build new pavement.

\section{CONCLUSIONS}

Various method of designing flexible pavement layer thickness was conducted and the major findings of this study can be itemized as follows:

i. Different design standard give different layer thickness. ii. Layer thickness plays a big role in determining the cost to construct new pavement

iii. Too thin of flexible pavement may cause to total pavement structure deflects before reached the design period.

\subsection{Suggestions and Recommendations}

This study only focuses on three design standard that is JKR Design Standard, AASHTO Design Standard and Asphalt Institute Design Standard. For future study, the more design standard should take into consideration such as BISAR Program, which is widely being used by Lembaga Lebuhraya Malaysia (LLM) and also by other outside highway and road consultant. So that more variation of design standard that can be compared in order to get the best design standard

\section{REFERENCES}

[1] Asphalt Institute Lexington Ky., "Asphalt Pavement for Highways and Streets", Manual Series No. 1, February 1991

[2] Asphalt Institute, Inc. "Asphalt Pavement Thickness Design Software, SW-1 User Guide”, 2005

[3] Fred L. Mannering et al, "Principles of Highway Engineering and Traffic Analysis", John Wiley and Son Publication, Third Edition, 2004

[4] J. Paul Guyer, P.E., R.A., Fellow ASCE, Fellow AEI, "Introduction to Flexible Pavement Design", 2009

[5] Jabatan Kerja Raya Malaysia, Arahan Teknik (Jalan) 5/85 "Manual On Pavement Design"

[6] Kevin D. Hall et al, "Development of Comprehensive Low-Volume Pavement Design Procedures" July 2000

[7] Mass Highway, Edition 2006 From http://www.mhd.state.ma.us/downloads/designGuide/C H_9.pdf

[8] New York State Department of Transportation, Albany, NY, "The New York State Thickness Design Manual For New and Reconstructed "Pavements", Oct 1994.

[9] Nicholas J. Garber et al, "Traffic and Highway Engineering", Brooks/Cole Thompson Learning Publication, 2002

[10] Syarifah A. Ibrahim, "KAS 2372 Highway Engineering", 2007

[11] The New Flexible Pavement Desig From http://www.state.nj.us/transportation/eng/pavement/pdf /new_flexible_design.pdf

[12] Tom V Mathew, "Introduction to Transportation Engineering”, March 22, 2007

[13] Yang H. Huang "Pavement Analysis and Design Second Edition", Pearson Education, Inc. 2004 